\title{
Pituitary adenylate cyclase-activating polypeptide, vasoactive intestinal polypeptide and their receptors: distribution and involvement in the secretion of Podarcis sicula adrenal gland
}

\author{
Salvatore Valiante*, Marina Prisco*, Rosaria Sciarrillo', Maria De Falco, Anna Capaldo, Flaminia Gay, \\ Piero Andreuccetti, Vincenza Laforgia and Lorenzo Varano
}

Dipartimento delle Scienze Biologiche, Sezione di Biologia Evolutiva e Comparata, Università Federico Il di Napoli, Via Mezzocannone, 8, 80134 Napoli, Italy

${ }^{1}$ Dipartimento di Scienze Biologiche ed Ambientali, Università degli Studi del Sannio, Benevento, Italy

(Correspondence should be addressed to S Valiante; Email: valiante@unina.it)

*(S Valiante and M Prisco contributed equally to this work)

\begin{abstract}
Vasoactive intestinal polypeptide (VIP) and pituitary adenylate cyclase-activating polypeptide (PACAP) are regulatory neuropeptides of the hypothalamus-hypophyseal-adrenal axis, acting via the common receptors $\mathrm{VPAC}_{1}$ and $\mathrm{VPAC}_{2}$ and the selective PACAP receptor $\mathrm{PAC}_{1}$. In the adrenal glands of the Italian wall lizard, Podarcis sicula, the presence of VIP in chromaffin cells, and the VIP-stimulated release of catecholamine and aldosterone in vivo, was previously shown. To examine the localization of both peptides and receptors and their mRNAs in the adrenal gland of $P$. sicula, immunohistochemistry and $i n$ situ hybridization were performed: PACAP and its $\mathrm{mRNA}$ were detected in chromaffin cells, $\mathrm{VPAC}_{1}$ was found associated with steroidogenic tissue, $\mathrm{VPAC}_{2}$ and $\mathrm{PAC}_{1}$ with chromaffin tissue. Using 'far western blot' technique, we showed the presence of specific binding sites for VIP/PACAP in the adrenal glands of the lizard. The effects of both VIP and PACAP on the adrenal cells of the
\end{abstract}

lizard were examined in vitro in adrenal cell co-cultures: both VIP and PACAP enhanced catecholamine, corticosterone and aldosterone release from adrenal cell co-culture in a time- and dose-dependent manner. The catecholamine release was inhibited by $\mathrm{PAC}_{1}$ antagonist and in $\mathrm{VPAC}_{2}$ immunoneutralized adrenal cells. The effects of VIP and PACAP on aldosterone secretion were counteracted by $\mathrm{VPAC}_{1}$ antagonist administration in vitro. Corticosterone secretion elicited by VIP was not blocked by $\mathrm{VPAC}_{1}$ antagonist, while the PACAP-induced release of corticosterone was blocked by the antagonist. Overall, our investigations indicate that these neuropeptides of the secretin superfamily can act not only as neurotransmitters but also as autocrine and paracrine regulators on chromaffin and cortical cells, being important mediators of the non-cholinergic system in the lizard adrenal gland.

Journal of Endocrinology (2008) 196, 291-303

\section{Introduction}

Vasoactive intestinal polypeptide (VIP) and pituitary adenylate cyclase-activating polypeptide (PACAP) belong to a wellknown regulatory peptide family that includes peptides such as secretin and glucagon. VIP and PACAP are known to be regulators within the hypothalamus-pituitary-adrenal axis (Nussdorfer \& Malendowicz 1998, Vaudry et al. 2000). The presence of both peptides in the chromaffin cells of several species, the selective distribution of their common receptors $\mathrm{VPAC}_{1}$ and $\mathrm{VPAC}_{2}$ and the PACAP exclusively receptor PAC $\mathrm{P}_{1}$ in the steroidogenic and chromaffin tissues forming adrenals of vertebrates (Vaudry et al. 2000, Laburthe et al. 2002, Conconi et al. 2006) strongly suggest that these neuropeptides can directly stimulate adrenal glands.

It has been demonstrated that PACAP is able to enhance the expression of tyrosine hydroxylase, dopamine $\beta$-hydroxylase and phenylethanolamine $N$-methyltransferase, the enzymes involved in the synthesis of catecholamines (Tonshoff et al. 1997, Choi et al. 1999, Corbitt et al. 2002). Moreover, it has been shown that VIP and PACAP stimulate catecholamine secretion from rat chromaffin cells in dose-dependent manner and aldosterone secretion from rat and human adrenal cortex (Nussdorfer \& Malendowicz 1998, Mazzocchi et al. 2002). In addition, it has been demonstrated that PACAP-induced catecholamine secretion from the rodent adrenal gland occurs through the activation of adenylyl cyclase and increased cytosolic calcium levels (Przywara et al. 1996). PACAP also induces catecholamine secretion from chromaffin cells both in Oncorhynchus mykiss (Montpetit \& Perry 2000) and in human adrenal cortex (Mazzocchi et al. 2002).

PACAP-induced corticosterone and aldosterone secretion has been shown in rat adrenal slices, but not on dispersed adrenocortical cells, suggesting that chromaffin and steroid cells 
must be present together to have a functional response (Andreis et al. 1995). PACAP-induced secretion of corticosterone and aldosterone from dispersed interrenal cells of Rana ridibunda and from perfused frog adrenal explants has been demonstrated (Nussdorfer \& Malendowicz 1998, Yon et al. 2001); moreover, it raises cyclic adenosine monophosphate in bovine glomerulosa cells (Bodart et al. 1997) and stimulates calcium mobilization in frog adrenocortical cells (Yon et al. 1994).

Despite this large amount of information about vertebrates, the investigations about these peptides in reptiles are scant, although this class has a crucial role in vertebrate evolution and the study of their endocrine system could suggest new insights into vertebrate endocrinology. The presence of VIP in chromaffin tissue, and VIP-stimulated release of catecholamines and aldosterone in vivo, was previously shown in the Italian wall lizard Podarcis sicula (Laforgia et al. 1999). It has also been demonstrated that VIP administration enhances the shift from noradrenaline to adrenaline production in the chromaffin cells (De Falco et al. 2003); further, we cloned lizard PACAP and showed that it is produced and widely expressed by $P$. sicula brain (Valiante et al. 2007).

Hence, to address the hypothesis of local control by neuropeptides in $P$. sicula adrenal glands, our present investigations concerned the localization of VIP, PACAP and their receptors in the adrenal gland of $P$. sicula, immunohistochemically and by in situ hybridization. Further, to better understand the signalling pathways existing in the regulation of adrenals by these regulatory peptides, we investigated $\mathrm{VPAC}_{1}, \mathrm{VPAC}_{2}$ and $\mathrm{PAC}_{1}$ receptor expressions. Moreover, we studied the effects of VIP and PACAP administration, alone or in presence of receptor antagonists, on in vitro cell co-cultures in order to clarify the role of these peptides in the crosstalk between chromaffin and steroidogenic cells.

\section{Materials and Methods}

\section{Animals}

The animals (number $=50 ; 14-16 \mathrm{~g}$ body weight each) were housed in soil-filled terrarium, fed ad libitum and exposed to natural photoperiod (16 h light: $8 \mathrm{~h}$ darkness) and temperature $\left(25^{\circ} \mathrm{C}\right.$ day $/ 18^{\circ} \mathrm{C}$ night). Captivity lasted 20 days to reverse capture-related stress (Manzo et al. 1994). The experiments were performed in accordance with the guidelines of institutional committees (Italian Ministry of Health) and the European Communities Council to minimize the number of animals used. All results were obtained through three independent experiments.

\section{Experimental procedure}

Lizards (325 $\mu \mathrm{g} / \mathrm{g}$ body weight) were anaesthetized using ketamine hydrochloride (Parke-Davis, Berlin, Germany) and killed; adrenals were excised and fixed for $24 \mathrm{~h}$ in Bouin's solution or $4 \%$ paraformaldehyde in PBS $(137 \mathrm{mM} \mathrm{NaCl}$, $\left.2 \cdot 7 \mathrm{mM} \mathrm{KCl}, 10 \mathrm{mM} \mathrm{Na}_{2} \mathrm{HPO}_{4}, 2 \mathrm{mM} \mathrm{KH}_{2} \mathrm{PO}_{4}\right) \mathrm{pH} 7 \cdot 4$. Adrenal samples were then dehydrated and embedded in paraffin wax. Paraffin-embedded glands were then sectioned at 5-7 $\mu \mathrm{m}$ and sections lifted onto baked superfrost glass slides (Menzel-Glaser, Braunschweig, Germany). Slides were then dried at $37{ }^{\circ} \mathrm{C}$ overnight and stored at $4{ }^{\circ} \mathrm{C}$ until use. Consecutive slides were utilized in immunohistochemistry and in situ hybridization procedures.

Some adrenals were incubated $48 \mathrm{~h}$ in complete F-10 Ham medium (see below) with $\mathrm{VPAC}_{1}$ antagonist (Ac-His ${ }^{1}$, D-Phe ${ }^{2}$, Lys ${ }^{15}$, Arg $^{16}$ ) VIP-(3-7), growth hormone-releasing factor-(8-27)- $\mathrm{NH}_{2}\left(\mathrm{VPAC}_{1}-\mathrm{A}\right) 10^{-3} \mathrm{M}$ (Phoenix Pharmaceuticals, Belmont, CA, USA) and then fixed and embedded in paraffin wax.

\section{Immunohistochemistry}

The immunohistochemistry procedure was described elsewhere (Valiante et al. 2007). Briefly, antigen unmasking was carried out in $10 \mathrm{mM}$ citrate buffer $(\mathrm{pH}$ 6.0) in a microwave oven for $2 \times 10 \mathrm{~min}$ at $400 \mathrm{~W}$. Sections were then washed $3 \times 5 \mathrm{~min}$ in $0.1 \mathrm{M}$ phosphate buffer $(\mathrm{pH} 7 \cdot 4)$, treated for $30 \mathrm{~min}$ with $0.3 \% \mathrm{H}_{2} \mathrm{O}_{2}$ to inactivate endogenous peroxidases and with 1:100 normal goat serum to block non-specific sites.

Overnight incubation was performed at $4{ }^{\circ} \mathrm{C}$ with a rabbit anti-PACAP27 antibody (Phoenix Pharmaceuticals) diluted $1: 300$ in normal goat serum or anti-VPAC 1 , anti-VPAC 2 and anti-PAC ${ }_{1}$ antibody (Santacruz Biotechnology, Santa Cruz, CA, USA) diluted 1:100. Afterwards, sections were washed in $0 \cdot 1 \mathrm{M}$ phosphate buffer $(\mathrm{pH} 7 \cdot 4)$ and covered with 1:1000 biotinylated anti-rabbit secondary antibody for $1 \mathrm{~h}$. Diami-

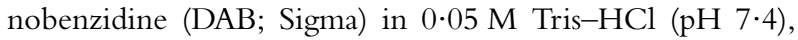
$0 \cdot 03 \% \mathrm{H}_{2} \mathrm{O}_{2}$ was used as substrate for peroxidase, to reveal immunoreactivity.

Finally, sections were counterstained with Mayer's hemalum and mounted with Histovitrex (Carlo Erba, Rodano, Italy). To check the specificity of reaction, two kinds of control were performed: a) negative control by omitting primary antibody and b) pre-incubating for $24 \mathrm{~h}$ at $4{ }^{\circ} \mathrm{C}$ anti-PACAP antibody with PACAP $10^{-6} \mathrm{M}$ (Phoenix Pharmaceuticals), centrifuging at $16000 \mathrm{~g}$ for $30 \mathrm{~min}$ and using supernatant as primary antibody.

\section{In situ hybridization}

For this study, we used digoxigenin-labelled RNA probes synthesized with DIG RNA labelling kit (Roche, Mannheim, Germany). They were complementary to the lizard PACAP (Valiante et al. 2007), human $\mathrm{VPAC}_{2}$ and mouse $\mathrm{VPAC}_{1}$ cDNA were kindly provided by $\mathrm{P}$ Robberecht and $\mathrm{M} \mathrm{S}$ O'Dorisio respectively (Svoboda et al. 1994, Karacay et al. 2001). Briefly, after transfection of JM109 cells, plasmids were recovered with Ultraclean miniplasmid kit (MoBIO Labs, Carlsbad, CA, USA) and used for an in vitro transcription 
reaction to synthesize both sense and antisense RNA probes of $300 \mathrm{bp}$ each. In situ hybridization procedure was performed as described elsewhere (Valiante et al. 2007). All solutions used in in situ hybridization were made with bidistilled water treated with $0 \cdot 1 \%$ diethylpyrocarbonate (Sigma) to inactivate RNases and then autoclaved. After dewaxing, the sections were permeabilized in $1 \mathrm{M}$ Tris- $\mathrm{HCl}, 0.5 \mathrm{M}$ EDTA containing $10 \mu \mathrm{g} / \mathrm{ml}$ proteinase $\mathrm{K}$, post-fixed in $4 \%$ paraformaldehyde in PBS and acetylated in $0 \cdot 1 \mathrm{M}$ triethanolamine $(\mathrm{pH} 8 \cdot 0)$ with $0 \cdot 25 \%$ acetic anhydride. Slides were immersed for $2 \mathrm{~h}$ at $70{ }^{\circ} \mathrm{C}$ in pre-hybridization buffer containing $50 \%$ deionized formamide (Applichem, Darmstadt, Germany), SSC $5 \times$ (Applichem), Denhardt solution $1 \times$ (Sigma), denatured salmon sperm DNA $100 \mu \mathrm{g} / \mathrm{ml}$ (Applichem), tRNA $100 \mu \mathrm{g} / \mathrm{ml}$ (Roche), 20\% dextran sulphate (Sigma) and then immersed overnight at $70{ }^{\circ} \mathrm{C}$ in the same buffer added with $2 \mathrm{ng} / \mu \mathrm{l}$ of appropriate sense or antisense riboprobes. After post-hybridization washes in $0.5 \times$ SSC and $20 \%$ formamide (Sigma), slides were immersed in NTE $(0.5 \mathrm{M} \mathrm{NaCl}, 10 \mathrm{mM}$ Tris (pH 7·2), $5 \mathrm{mM}$ EDTA), containing RNase A $10 \mu \mathrm{g} / \mathrm{ml}$ (Applichem) and then blocked with 2\% blocking reagent (Roche), 10\% normal sheep serum (NSS, Sigma) in $100 \mathrm{mM}$ maleic acid buffer. To reveal the reaction, an anti-DIG alkaline phosphatase-conjugated antibody (Roche) was used and BM Purple or NBT/BCIP (Roche) colorimetric reaction was performed following manufacturer's instruction. Sections were counterstained with nuclear Fast Red (Vector, Burlingame, CA, USA).

\section{Images elaboration}

Both in situ and immunohistochemical signals were analysed with Axioskop System (Zeiss, Oberkochen, Germany) under light conditions and images acquired by KS 3002.0 software (Zeiss).

\section{VPAC receptor far western blot}

Protocol for membrane preparation was described elsewhere (Cao et al. 1995) and modified as follows: to isolate membrane proteins, $P$. sicula adrenals were quickly removed, immersed in $5 \mathrm{mM}$ HEPES ( $\mathrm{pH} 7 \cdot 4$ ), $1 \mathrm{mM}$ EDTA and homogenized in ice cold potter. Samples were centrifuged at $4000 \mathrm{~g}$ at $4{ }^{\circ} \mathrm{C}$ for $20 \mathrm{~min}$ to eliminate nuclei and cell debris; supernatant, containing membranes, was recovered and centrifuged at $40000 \mathrm{~g}$ at $4{ }^{\circ} \mathrm{C}$ for $20 \mathrm{~min}$; the pellet was resuspended in $20 \mathrm{mM}$ HEPES ( $\mathrm{pH} 7 \cdot 4$ ), $1 \mathrm{mM}$ EDTA, $0.5 \mathrm{mM}$ phenylmethylsulphonyl fluoride, $0 \cdot 1 \mathrm{mg} / \mathrm{ml}$ bacitracin, $0 \cdot 1 \mathrm{mg} / \mathrm{ml}$ soybean trypsin inhibitor, $5 \mu \mathrm{g} / \mathrm{ml}$ antipain, $5 \mu \mathrm{g} / \mathrm{ml}$ leupeptin, $1 \mu \mathrm{g} / \mathrm{ml}$ pepstatin and re-homogenized to extract cell membranes proteins. After a centrifugation at $40000 \mathrm{~g}$ at $4{ }^{\circ} \mathrm{C}$ for $20 \mathrm{~min}$, the pellet, containing membrane proteins, was resuspended in the previous buffer, dialysed overnight at $4{ }^{\circ} \mathrm{C}$ and protein content assessed by the Pierce method (Pierce, Rockford, IL, USA) in about $2 \mu \mathrm{g} / \mu \mathrm{l}$.
SDS-PAGE was performed using a 10\% acrylamide gel under non-reducing conditions (Laemmli 1970); $12.5 \mu \mathrm{l}$ medium containing $20 \mu \mathrm{g}$ protein and the molecular standard markers (Sigma) were loaded in separate lanes. Proteins were transferred on nitrocellulose membrane (Schleicher and Schuell, Dassel, Germany), which was blocked with 5\% non-fat milk (Bio-Rad) in TBS (10 mM Tris-HCl (pH 7·5), $50 \mathrm{mM} \mathrm{NaCl}$ ). 'Far western blot' technique to display-binding protein was carried out (Hall 2004). The membrane was washed in TBS with $0 \cdot 1 \%$ Tween 20 and $1 \%$ BSA (washing buffer), and incubated with VIP or PACAP27 (Phoenix Pharmaceuticals) 1:100 in washing buffer for $1 \mathrm{~h}$ at room temperature, then with rabbit anti-VIP or anti-PACAP27 antibodies (Phoenix Pharmaceuticals) 1:300 in washing buffer overnight at $4{ }^{\circ} \mathrm{C}$; after removing the antibody, excess membrane was incubated with anti-rabbit biotinylated polyclonal secondary antibody (Pierce) for $1 \mathrm{~h}$ at room temperature. The reaction was revealed using an avidin-biotin peroxidase complex (Pierce) following the manufacturer's instructions, DAB (Sigma) as chromogen in $0.03 \%$ of $\mathrm{H}_{2} \mathrm{O}_{2}$ in TBS (pH 7.5). The controls were carried out by omitting VIP, PACAP or anti-VIP and anti-PACAP incubation.

\section{VIP and PACAP immunoprecipitation and dot blot peptide analysis}

To estimate the VIP and PACAP secretion in the co-culture medium, dot blot assay was performed as described elsewhere (Nezlin 2000). Complete F-10 HAM (see below) was collected from control co-culture after $24 \mathrm{~h}$. Immunoprecipitation with anti-VIP or anti-PACAP27 antibodies linked to protein-A acrylic beads conjugated (Sigma) was carried out overnight at $4{ }^{\circ} \mathrm{C}$. Peptide-antibody beads complexes were then separated by centrifugation at $12000 \boldsymbol{g}$ for $5 \mathrm{~min}$. Pellets were resuspended in PBS, heated at $95^{\circ} \mathrm{C}$ for $5 \mathrm{~min}$, to remove protein-A antibody complex, supernatants collected by centrifugation at $12000 \mathrm{~g}$ for $5 \mathrm{~min}$. One microlitre per sample, containing the purified secreted peptides, was spotted on a nitrocellulose filter (Schleicher and Schuell). Standard PACAP and VIP 0.1 M were diluted 3, 10, 30, 100 and 1000 times and used to generate a calibration curve. To determine the unspecific reaction between the medium and antibodies, fresh sterile F-10 HAM was spotted at the same peptide dilution. Distilled water was used as negative control. Filter was blocked for $1 \mathrm{~h}$ in $5 \%$ non-fat dry milk (Bio-Rad), $0 \cdot 2 \%$ Tween-20 in TBS to avoid unspecific binding, then incubated $1 \mathrm{~h}$ with the appropriate primary antibody, 1:300 diluted in the same buffer. After washing in TBS-Tween, biotinylated secondary antibody (Vector) was added for $30 \mathrm{~min}$. Filters were then incubated for $30 \mathrm{~min}$ in a solution of streptavidin peroxidase complex and $\mathrm{DAB}$ (Vector) was used to detect peptides, following manufacturer's instruction. The acquisition of filters was carried out as previously described (Bjornsson 1998). Filters were acquired using Epson Perfection 1660 photo (Epson, Cinisello Balsamo, Italy) scanner with reflectance mode, $\gamma$-curve set at $1 \cdot 0$ and images saved in $\mathrm{RGB}$ 
mode. Densitometric computer analysis of spots was then performed with Scion Image software (Scion Corporation, Frederick, MA, USA) according to Malagoli et al. (2004). Optical values of secreted peptides were compared with optical values of known dilutions of pure peptides and the evaluation of VIP and PACAP content in the medium was obtained.

\section{P. sicula cell co-culture}

All solutions were $0.22 \mu \mathrm{m}$ filtered, autoclaved and UV irradiated overnight. Adrenals were immersed in sterile cold physiologic solution for reptiles $(0 \cdot 75 \% \mathrm{NaCl})$ and transferred in the enzymatic solution made of: F-10 HAM (Sigma), 0.7\% collagenase I (Sigma), 0.1 mg/ml DNase I (Sigma), 0.16\% dispase (Sigma), $2 \mathrm{mM}$ L-glutamine (Invitrogen), 10\% FBS (Invitrogen), $100 \mathrm{U} / \mathrm{ml}$ penicillin (Invitrogen), $100 \mu \mathrm{g} / \mathrm{ml}$ streptomycin (Invitrogen) and $40 \mu \mathrm{g} / \mathrm{ml}$ gentamycin (Invitrogen). The digested solution was centrifuged at $400 \mathrm{~g}$ for $10 \mathrm{~min}$ at $4{ }^{\circ} \mathrm{C}$ and the pellet resuspended in complete F-10 HAM medium containing $2 \mathrm{mM}$ L-glutamine, 10\% FBS heat inactivated, $100 \mathrm{U} / \mathrm{ml}$ penicillin, $100 \mu \mathrm{g} / \mathrm{ml}$ streptomycin, $40 \mu \mathrm{g} / \mathrm{ml}$ gentamycin and $0 \cdot 2 \%$ BSA (Applichem). Cell viability assessed by trypan blue staining was $>90 \%$. Finally, cells were incubated at $25{ }^{\circ} \mathrm{C}$ with $5 \%$ of $\mathrm{CO}_{2}$ for $24 \mathrm{~h}$ at a concentration of $2 \times 10^{5}$ cells/well, medium collected and used as control for both basal hormone and peptide evaluation (baseline).

All peptides and antagonists were dissolved in complete medium to the required concentrations. To assess the action of VIP and PACAP, a range of concentrations from $10^{-11} \mathrm{M}$ to $10^{-5} \mathrm{M}$ were used and medium gathered after $1 \mathrm{~h}$. To determine the time-course curve, VIP or PACAP $10^{-7} \mathrm{M}$ was added to the medium and after 1, 3, 6 and 24 h medium was collected and stored at $-20{ }^{\circ} \mathrm{C}$ until hormone assay. To study the receptor pathways involved in the peptide-induced adrenal cell response, several receptor antagonists were added in combination: $\mathrm{VPAC}_{1}-\mathrm{A} 10^{-6} \mathrm{M}^{-}$antagonist of $\mathrm{VPAC}_{1}$ receptor and/or PACAP 6-38 $10^{-6} \mathrm{M}$ (Phoenix Pharmaceuticals) selective antagonist of $\mathrm{PAC}_{1}$ receptor and propanolol (Sigma) antagonist of $\beta$-adrenoceptors; 30 min later, cells were incubated with VIP or PACAP $10^{-7} \mathrm{M}$ and the medium was collected after $1 \mathrm{~h}$. To block the $\mathrm{VPAC}_{2}$ pathway, immunoneutralization according to Reed et al. (1999) was performed. Lizards were i.p. injected daily with $\mathrm{VPAC}_{2}$ antiserum $10 \mu \mathrm{l} / 10 \mathrm{~g}$ (Santacruz Biotechnology) or an equal volume of NSS (controls). On day 10 of injection ( $2 \mathrm{~h}$ after injection), adrenals were removed, cells dispersed, placed in complete F-10 HAM and then immediately treated with antagonists as described above.

\section{Hormone assay}

Corticosterone was measured, using a sensitive and highly specific radioimmunoassay kit (ICN Biomedicals, Costa Mesa, CA, USA), as previously described (De Falco et al. 2004). Corticosterone titres in picograms per millilitre were calculated using the standard curve generated in the assay with known amounts of radio-inert corticosterone purchased from
Amersham; sensitivity was $176 \mathrm{pg} / \mathrm{ml}$. Cross-reactivity of the corticosterone antiserum with other steroids was given by the manufacturer. Inter- and intra-assay coefficients of variation were 3.4 and $5 \cdot 8 \%$ respectively. Aldosterone was measured using a sensitive and highly specific radioimmunoassay kit (ALDO-RIACT, Schering, France) following the manufacturer's instructions; sensitivity was $70 \mathrm{pg} / \mathrm{ml}$. Cross-reactivity of the aldosterone antiserum with other steroids was given by the manufacturer. Inter- and intra-assay coefficients of variation were $7 \cdot 7$ and $8 \cdot 4 \%$ respectively.

As previously described, $200 \mu \mathrm{l}$ catecholamines (noradrenaline and adrenaline) were extracted from the medium by the alumina adsorption method (De Falco et al. 2004). Catecholamine levels were measured by high-performance liquid chromatography (HPLC) with electrochemical detection. The HPLC incorporates a Varian Star 9012 solvent delivery system (Varian, Walnut Creek, CA, USA) coupled to a Princeton Applied Research 400 electrochemical detector (EG \& G Instruments, Princeton, NJ, USA). Concentrations were calculated relative to appropriate standards and with 3,4-dihydroxybenzylalamine hydrobromide as an internal standard in all determinations, with a detection limit of $0 \cdot 1 \mathrm{nmol} / \mathrm{l}$. Catecholamine concentration was calculated as the sum of noradrenaline and adrenaline values and expressed in $\mathrm{pg} / \mathrm{ml}$.

\section{Statistical analysis}

All data were expressed as means \pm s.E.M. The non-parametric Kruskal-Wallis analysis with Bonferroni method was performed to test whether peptides have a significant effect on basal levels of aldosterone, corticosterone and catecholamine release. The non-parametric Kendall coefficient of correlation was used to estimate the linearity of relation between the arbitrary optic units and the concentrations of peptides in the dot blot assay.

\section{Results}

Chromaffin and steroidogenic tissues show a distinctive histology in the adrenal glands of $P$. sicula. In contrast to mammals, chromaffin cells form a dorsal ribbon placed in the outer region of the adrenal surrounding inner steroidogenic ribbons (Fig. 1a); in addition, scattered adrenaline cells are found between steroidogenic cells (Fig. 1a).

\section{Immunohistochemistry and in situ hybridization}

PACAP PACAP immunoreactivity was localized at a strong level of expression in both noradrenaline and adrenaline chromaffin cells of adrenal ribbon; moreover, a strong immunoreactivity was localized in the adrenaline islets too (Fig. 1b). Furthermore, a weaker PACAP immunoreactivity was also found in steroidogenic cells near to the plasmatic membrane (Fig. 1b). This steroidogenic PACAP immunopositivity was 

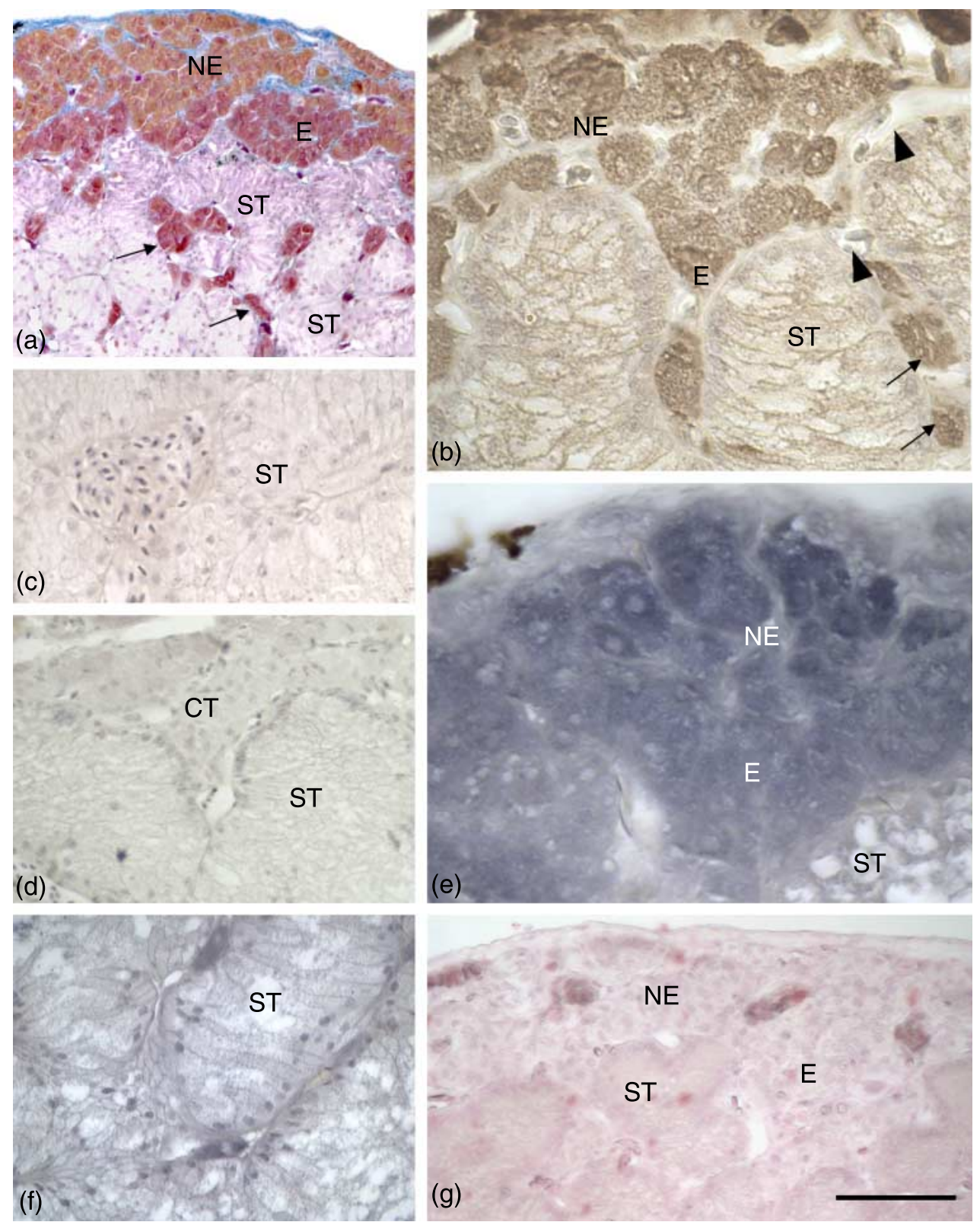

Figure 1 PACAP and its messenger in the adrenal gland of Podarcis sicula. The $20 \mathrm{~mm}$ scale bar corresponds to: (a, d and g) $50 \mu \mathrm{m}$; (b, c and f) $16.5 \mu \mathrm{m}$; (e) $20 \mu \mathrm{m}$. (a) The histology of the adrenal gland of Podarcis sicula is evidenced by Mallory's staining by which noradrenaline cells (NE) and adrenaline cells (E) are orange and red coloured respectively. NE and E cells are arranged in a dorsal ribbon lying on steroidogenic tissue (ST). Several groups of adrenaline cells (black arrows) are dispersed between the steroidogenic tissue.

(b) Immunohistochemistry for PACAP: section treated with PACAP antibody. Adrenaline islets immunoreactive to PACAP antibody (black arrows). A weak labelling occurs in steroidogenic tissue (ST). Two blood vessels (black arrow head) containing red blood cells without signal indicate the specificity of the immunohistochemical reaction. (c) Section of an adrenal gland pre-incubated with $\mathrm{VPAC}_{1}-\mathrm{A} 10^{-3} \mathrm{M}$ and then with PACAP antibody. Steroid cells lack of PACAP immunoreactivity. (d) Immunohistochemistry for PACAP: control section-treated pre-incubating antibody with PACAP $10^{-6} \mathrm{M}$ shows no labelling. Chromaffin tissue (CT). (e) In situ hybridization for PACAP mRNA: section treated with antisense riboprobe showing specific labelling of chromaffin cells and the lack of signal in the steroidogenic tissue. (f) In situ hybridization for PACAP mRNA: adrenaline cells, dispersed between steroidogenic tissues, are labelled for PACAP messenger. (g) In situ hybridization for PACAP mRNA: control section hybridized with sense riboprobe shows no labelling. Full colour version of this figure available via http://dx.doi.org/10.1677/JOE-07-0127 

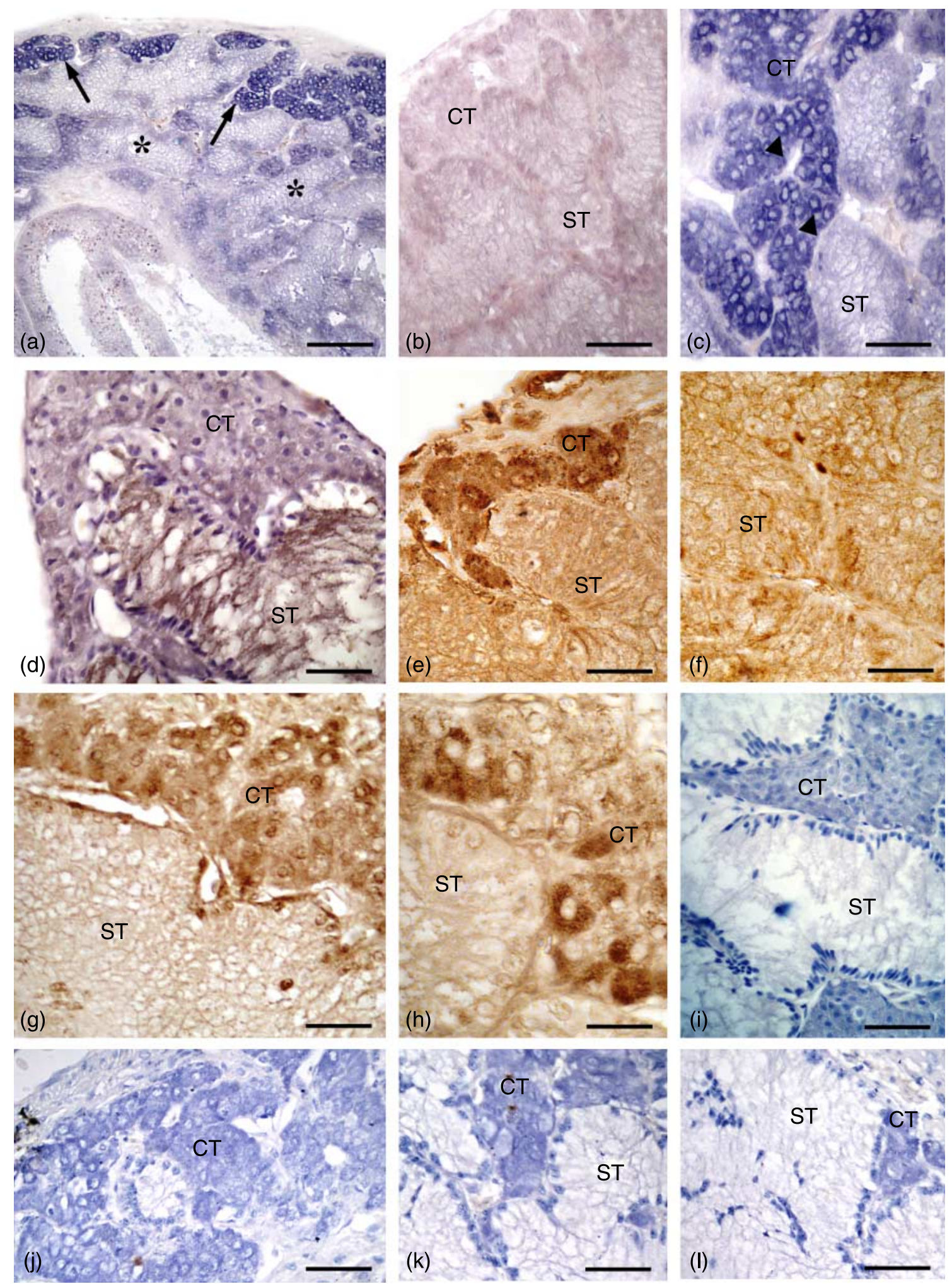
reversed after pre-treatment with $\mathrm{VPAC}_{1}-\mathrm{A} 10^{-3} \mathrm{M}$ (Fig. 1c). Controls treated by pre-incubating antibody with PACAP $10^{-6} \mathrm{M}$ (Fig. 1d) or by omitting primary antibody (data not shown) showed no labelling in both tissues.

The in situ hybridization performed at high-stringency conditions showed the presence of PACAP mRNA exclusively in both noradrenaline and adrenaline chromaffin cells, while steroidogenic cells did not express PACAP messenger (Fig. 1e). In addition, a strong signal was found in the adrenaline cells that compose islets scattered in the steroidogenic tissue (Fig. 1f). Chromaffin and steroidogenic tissues hybridized with sense probe were lacking hybridization signal (Fig. 1g).

\section{VIP/PACAP receptors}

Using $\mathrm{VPAC}_{2}$ riboprobes on adrenal sections, the chromaffin ribbon was extensively labelled (Fig. 2a and c). Labelling for $\mathrm{VPAC}_{2}$ receptor mRNA occurred in the cytoplasmic portion of chromaffin cells but not in the nuclei (Fig. 2c). In contrast to the strongly labelled chromaffin cells, complete lack of hybridization signal in the steroidogenic tissue was found, clearly evident at higher magnification (Fig. 2a and c).

To localize $\mathrm{VPAC}_{1}$ mRNA, we used a $\mathrm{VPAC}_{1}$ riboprobe. Intriguingly, we observed a different distribution pattern compared with $\mathrm{VPAC}_{2}$. VPAC 1 was exclusively localized within the cytoplasmic portion of steroidogenic cells (Fig. 2d). To test the specificity of our in situ hybridization experiments, two sorts of control were used: 1) a negative control performed with sense riboprobes did not show labelling in both tissues (Fig. 2b) and 2) a positive control performed using rat brain sections that certainly express VIP receptors (Usdin et al. 1994; data not shown).

$\mathrm{VPAC}_{2}$ immunoreactivity was associated with the chromaffin tissue (Fig. 2e). The labelling extensively occurs in both noradrenaline and adrenaline cells (Fig. 2e).

Immunoreactivity for $\mathrm{VPAC}_{1}$ was found in the steroidogenic cells (Fig. 2f). Interestingly, it localizes in the cytoplasm near the nuclei, between them and the membranes which are in proximity of blood vessels (Fig. 2f).

Immunoreactivity for $\mathrm{PAC}_{1}$ is restricted to the chromaffin cells exclusively (Fig. 2g). Further, not all chromaffin cells express labelling for $\mathrm{PAC}_{1}$, but immunoreactivity seems to be found only in adrenaline cells, which are located closer to the steroidogenic tissue (Fig. 2h).

Negative controls for VIP and PACAP receptor immunohistochemistry show no immunoreactivity (Fig. 2i-l).

\section{VIP/PACAP receptor far western blot}

Far western blot experiments performed with VIP/anti-VIP showed two bands that represent binding sites for VIP approximately at 45 and $55 \mathrm{kDa}$ (Fig. 3a) respectively. Moreover, the far western blot performed with PACAP/ anti-PACAP revealed an additional band at $60 \mathrm{kDa}$ (Fig. 3b). Controls, obtained omitting peptides (Fig. $3 \mathrm{c}$ and d) or appropriate antibodies (data not shown), showed no bands.

\section{Effects of VIP on adrenal cell co-cultures}

Steroidogenic and chromaffin cells co-cultured in the presence of VIP $\left(10^{-11} \mathrm{M}-10^{-5} \mathrm{M}\right)$ increased their secretion of catecholamines, corticosterone and aldosterone (Fig. 4). Catecholamine secretion by chromaffin cells was strongly increased in a dose-dependent manner with a maximum effect at $10^{-7} \mathrm{M}$ (Fig. 4). Also, corticosterone secretion by steroidogenic cells was affected by VIP $\left(10^{-9} \mathrm{M}-10^{-7} \mathrm{M}\right)$ in a dose-dependent manner increasing about $1 \cdot 7$-fold at $10^{-7} \mathrm{M}$ (Fig. 4). By contrast, aldosterone secreted by steroidogenic cells was weakly enhanced by VIP reaching the maximum effect at $10^{-7} \mathrm{M}$ (Fig. 4). Further, desensitization to VIP occurs at $10^{-5} \mathrm{M}$ since the dose is 100 - to 1000 -fold higher than physiological levels of VIP (Fig. 4).

Once the maximum effective VIP dose was established at $10^{-7} \mathrm{M}$, we decided to verify whether VIP can stimulate steroidogenic and chromaffin cell co-cultures in a timedependent manner. We showed that catecholamine secretion was determined in a time-dependent manner with a strong increase after $1 \mathrm{~h}$ and reaching the maximum level after $6 \mathrm{~h}$ (Fig. 5a). This VIP-induced enhancement was only weakly affected by contemporary administration of VIP $\left(10^{-7} \mathrm{M}\right)$ plus $\mathrm{VPAC}_{1}-\mathrm{A}\left(10^{-6} \mathrm{M}\right.$; Fig. 5a). Corticosterone was strongly increased by VIP in a time-dependent manner by about twofold after $6 \mathrm{~h}$ (Fig. 5b). VPAC $_{1}-\mathrm{A}\left(10^{-6} \mathrm{M}\right)$ administration did not modify the corticosterone response to VIP $\left(10^{-7}\right.$ M; Fig. 5b). Aldosterone secretion was faintly

Figure 2 VPAC mRNAs in the adrenal gland of Podarcis sicula. The $20 \mathrm{~mm}$ scale bar corresponds to: a) $100 \mu \mathrm{m}$; b) $83 \mu \mathrm{m}$; c) $25 \mu \mathrm{m}$; d) $25 \mu \mathrm{m}$; e) $25 \mu \mathrm{m}$; f) $20 \mu \mathrm{m}$; g) $20 \mu \mathrm{m}$; h) $13 \mu \mathrm{m}$; i) $20 \mu \mathrm{m}$; j) $25 \mu \mathrm{m}$; k) $20 \mu \mathrm{m}$; l) $20 \mu \mathrm{m}$. (a) Podarcis sicula adrenal gland section hybridized with antisense riboprobe complementary to $\mathrm{VPAC}_{2}$ mRNA. The labelling of chromaffin cells (arrows) is evident while steroidogenic cells are not labelled (stars). Abbreviations as in Fig. 1. (b) Negative control: Podarcis sicula adrenal gland section, hybridized with sense probe, which lacks hybridization signal. (c) VPAC 2 riboprobe labelling occurs in cytoplasmic portion of chromaffin cells that possess nuclear region without signal (black arrow heads). (d) In situ hybridization for $\mathrm{VPAC}_{1}$ mRNA revealed with NBT/BCIP colorimetric reaction. Steroidogenic

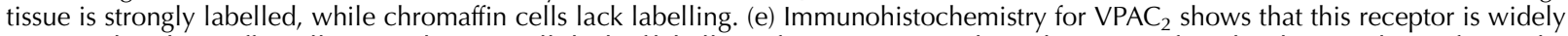
expressed in chromaffin cells. Steroidogenic cells lack of labelling. (f) VPAC ${ }_{1}$ immunohistochemistry is found in the cytoplasm of steroid cells

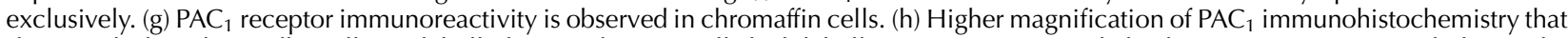
shows only few chromaffin cells are labelled. Steroidogenic cells lack labelling. (i) $\mathrm{VPAC}_{1}$ in situ hybridization negative control obtained using sense probe. No signal is evident. Sections were counterstained with Mayer's hemalum. (j, $k$ and I) VPAC ${ }_{2}, V_{P A C}$ and $P P_{1}$ immuno histochemistry negative controls respectively. Sections were counterstained with Mayer's hemalum. Full colour version of this figure available via http://dx.doi.org/10.1677/JOE-07-0127 


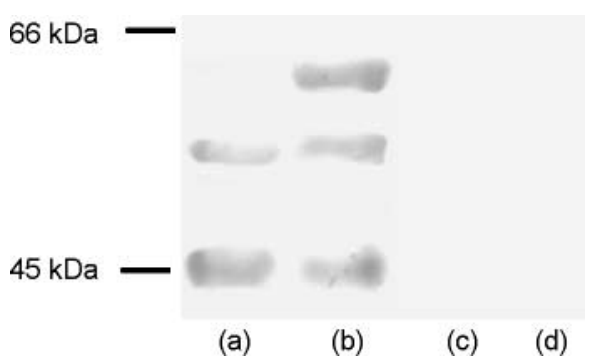

Figure 3 Far western blot of membrane proteins extracted from adrenal glands of Podarcis sicula. The blots were incubated with VIP and anti-VIP antibody (a) or PACAP and anti-PACAP antibody (b). There are two bands positive to VIP, three binding sites for PACAP of $\sim 45,55$ and 60 kDa respectively. Negative controls were performed by omitting VIP (c), PACAP (d) or appropriate primary antibodies (data not shown).

enhanced by VIP reaching a maximum increase after $24 \mathrm{~h}$. Intriguingly, aldosterone secretion by steroidogenic cells was completely inhibited by $\mathrm{VPAC}_{1}-\mathrm{A}\left(10^{-6} \mathrm{M}\right)$ administration (Fig. 5b). This dataset strongly suggests that multiple receptor pathways are involved in the adrenal control by VIP. Hence, to identify the receptor pathways implicated in the VIPinduced secretion in adrenal cell co-cultures, we performed several experiments blocking all known receptors involved but one at a time (see materials and methods). The administration of VIP in co-cultures where only the $\mathrm{VPAC}_{2}$ pathway was allowed to be active evokes a catecholamine release of $+44 \%$ on the basal secretion, but not steroid secretion (Fig. 5c). When VIP was added to co-cultures where only $\mathrm{VPAC}_{1}$ pathway was available, catecholamines did not rise and steroid secretion increased by +33 and $+75 \%$ for corticosterone and aldosterone respectively (Fig. 5d).

\section{Effects of PACAP on adrenal cell co-cultures}

Steroidogenic and chromaffin cells co-cultured in the presence of PACAP $\left(10^{-11}-10^{-5} \mathrm{M}\right)$ secreted increasing levels of corticosterone, aldosterone and catecholamines (Fig. 6). PACAP dose dependently increased catecholamines to a very

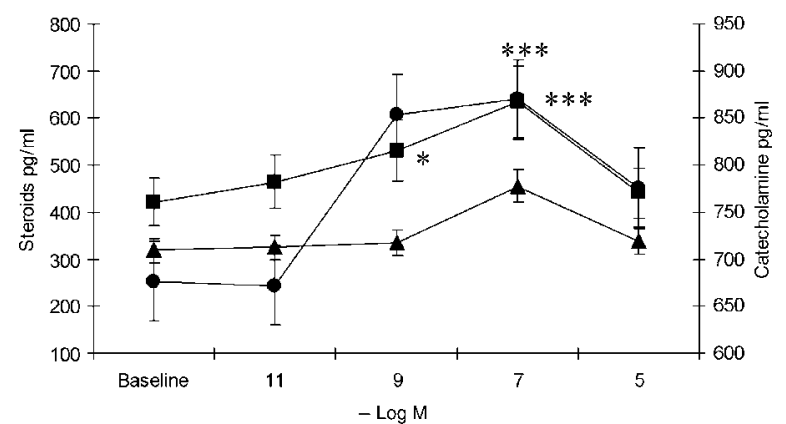

Figure 4 Effects of VIP on in vitro-cultured adrenal cells. Data are expressed in $\mathrm{pg} / \mathrm{ml} \pm$ S.E.M. Dose-response of catecholamine ( $\bullet$ ), corticosterone ( $\mathbf{\square})$ and aldosterone ( $\mathbf{\Delta})$ to VIP administration. ${ }^{*} P<0 \cdot 05$; ${ }^{* * *} P<0 \cdot 001$. low amount $\left(10^{-9} \mathrm{M}\right)$ showing maximal effect at $10^{-7} \mathrm{M}$ (Fig. 6). PACAP $\left(10^{-11}-10^{-7} \mathrm{M}\right)$ elevated corticosterone and aldosterone levels with highest values, +106 and $+74 \%$ respectively, at concentration of $10^{-7} \mathrm{M}$ (Fig. 6).

Once the maximum effective PACAP dose was established at $10^{-7} \mathrm{M}$, we decided to verify the time-dependent effects of PACAP. A time-course curve showed that PACAP enhanced catecholamine secretion $(+27 \%)$ as early as $1 \mathrm{~h}$, with a maximum stimulatory effect at $24 \mathrm{~h}$ (Fig. 7a). Intriguingly, we observed a slight decrease of the long-term releasing by chromaffin cells $(6-24 \mathrm{~h})$ contemporarily adding $\mathrm{VPAC}_{1}-\mathrm{A}$ and PACAP (Fig. 7a). Time-dependent curves showed a strong release of corticosterone and aldosterone under PACAP stimulation within $6 \mathrm{~h}$, keeping high levels up to $24 \mathrm{~h}$ (Fig. 7b). In particular, in vitro PACAP administration had a strong effect on the corticosterone, increasing its secretion of $119 \%$ with respect to baseline after $24 \mathrm{~h}$ (Fig. $7 \mathrm{~b}$ ). After $24 \mathrm{~h}$, aldosterone reached its peak value of $50 \%$ above basal secretion (Fig. 7b). The PACAP induced corticosterone, and aldosterone secretion was strongly inhibited by $\mathrm{VPAC}_{1}-\mathrm{A}$ (Fig. 7b).

Similarly to VIP, to detect the receptor pathways involved in the PACAP-induced secretion of adrenal cells, we carried out several experiments; the administration of PACAP in co-cultures where both $\mathrm{VPAC}_{1}$ and $\mathrm{VPAC}_{2}$ are available provokes a large catecholamine release and a still considerable steroid secretion (Fig. 7c). When only $\mathrm{PAC}_{1}$ pathway was available, PACAP induces a massive release of catecholamines $(+61 \%)$, while steroids were not influenced (Fig. 7d). The PACAP-induced response through the $\mathrm{VPAC}_{2}$ pathway also induces an increase of catecholamines release $(+55 \%)$, whereas it did not significantly affect corticosterone and aldosterone secretion (Fig. 7e). The PACAP-induced response through the $\mathrm{VPAC}_{1}$ pathway enhances the secretion of corticosterone and aldosterone but only a $6 \%$ increase in catecholamine secretion after $24 \mathrm{~h}$ (Fig. 7f).

\section{Dot blot peptide analysis}

The release of PACAP in the culture medium was $0.03 \mathrm{pmol} / \mathrm{ml}$ and VIP $0.16 \mathrm{pmol} / \mathrm{ml}$, after $24 \mathrm{~h}$ of co-culture (Fig. 8). Controls did not show immunoreaction (data not shown).

\section{Discussion}

A growing body of evidence indicates that VIP and PACAP are contained in numerous peripheral tissues where they have been found to exert their pleiotropic effects through the interaction with three receptors termed $\mathrm{PAC}_{1}$, which is coupled by PACAP exclusively, $\mathrm{VPAC}_{1}$, and $\mathrm{VPAC}_{2}$, which are common receptors with relative affinity for these peptides (Vaudry et al. 2000, Conconi et al. 2006).

Previous immunohistochemical investigations on adrenal glands of the Italian wall lizard $P$. sicula showed a VIP immunopositivity localized in chromaffin cells, ganglion cells and nerve fibres (Laforgia et al. 1999), suggesting a possible role 


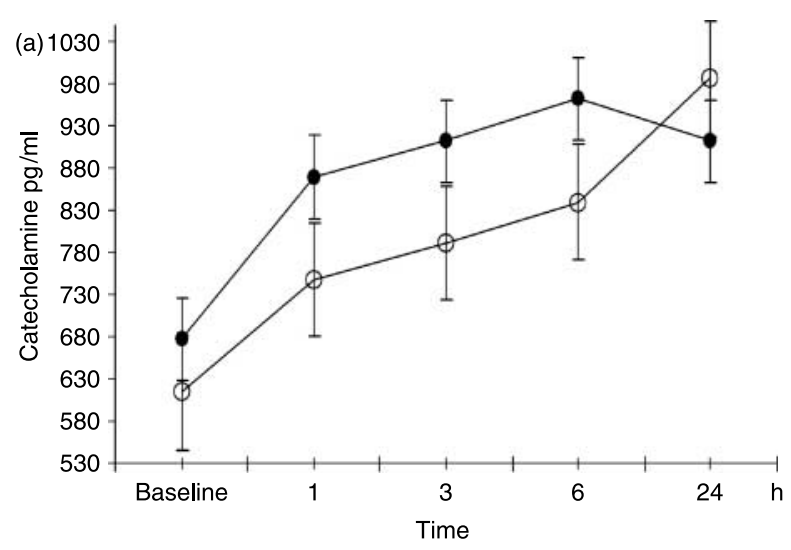

(b)
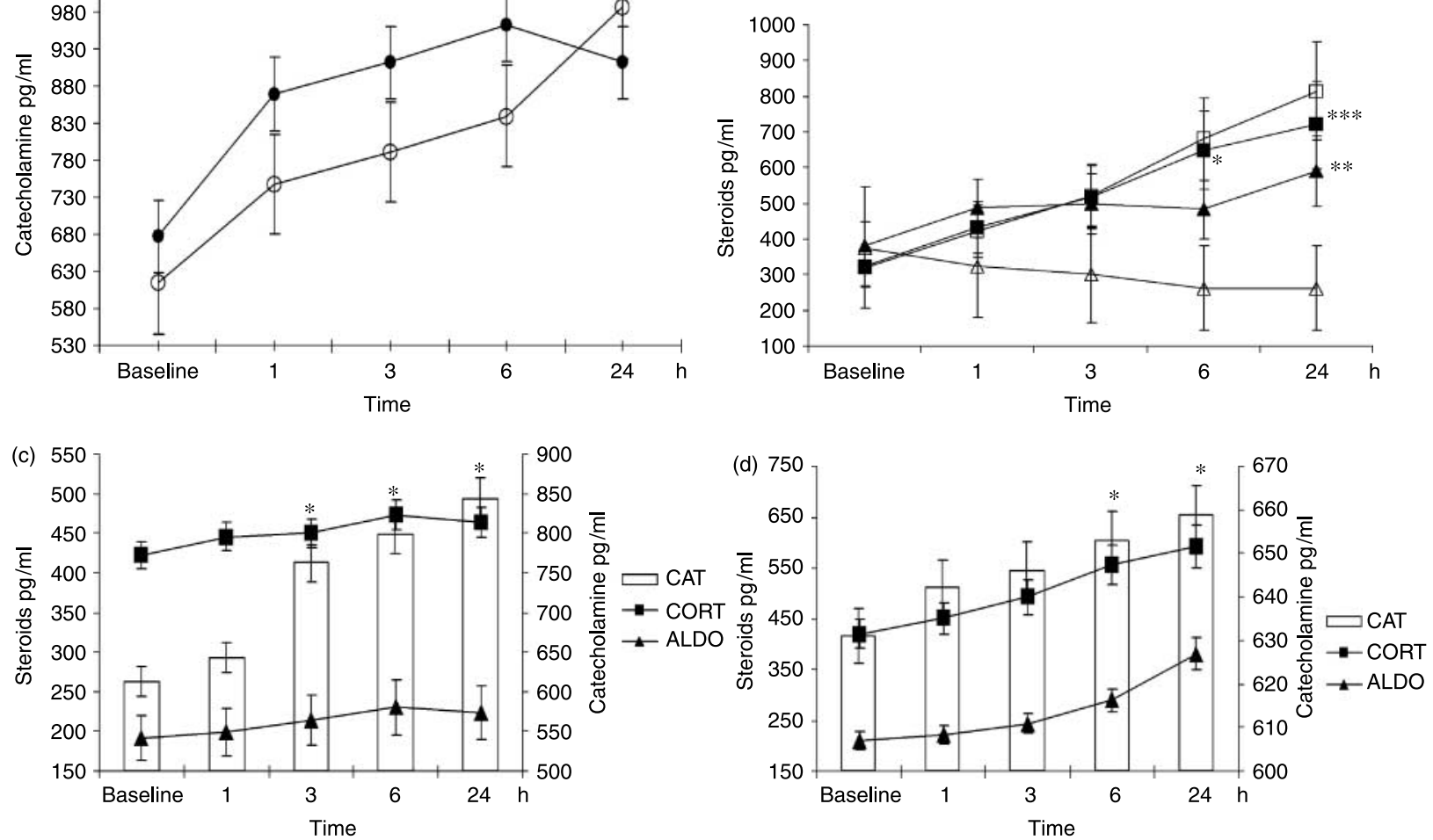

Figure 5 Effects of VIP $10^{-7} \mathrm{M}$ administration on co-cultured adrenal cells. Data are expressed in pg/ml \pm s.E.M. PACAP 6-38 (10 $\left.{ }^{-6} \mathrm{M}\right)$ was added, where appropriate, to avoid endogenous PACAP stimulation. (a) Time course of catecholamine after VIP $(\bullet)$ or VIP + VPAC 1 -A $\left(10^{-6} \mathrm{M}\right)(O)$ administration. $P<0 \cdot 01$ versus baseline. (b) Time course of corticosterone (squares) and aldosterone (triangles) after VIP (black) or $\mathrm{VIP}+\mathrm{VPAC}_{1}-\mathrm{A}$ (empty) administration. ${ }^{*} P<0 \cdot 05 ;{ }^{* *} P<0 \cdot 01$; ${ }^{* * *} P<0 \cdot 001$ versus baseline. ${ }^{* *} P<0 \cdot 01$ when $\mathrm{VIP}$ is compared with VIP plus antagonist for aldosterone. (c) VIP effects on catecholamine and steroids through $\mathrm{VPAC}_{2}$ receptor exclusively. To block simultaneously $\mathrm{VPAC}_{1}, \beta$-adrenoceptors and $\mathrm{PAC}_{1}$, samples were treated with $\mathrm{VIP}+\mathrm{VPAC}_{1}-\mathrm{A}\left(10^{-6} \mathrm{M}\right)+$ Propanolol $\left(10^{-6} \mathrm{M}\right)+\mathrm{PACAP}$ $6-38\left(10^{-6} \mathrm{M}\right)$ respectively. ${ }^{*} P<0 \cdot 05$. (d) VIP effects on catecholamine and steroids through $\mathrm{VPAC}_{1}$ receptor exclusively. To block $\mathrm{PAC}_{1}$, $\beta$-adrenoceptors and $\mathrm{VPAC}_{2}$ pathways, $\mathrm{VPAC}_{2}$ immunoneutralized adrenals were treated with $\mathrm{VIP}+$ Propanolol $\left(10^{-6} \mathrm{M}\right)+\mathrm{PACAP} 6-38$ $\left(10^{-6} \mathrm{M}\right) . * P<0 \cdot 05$.

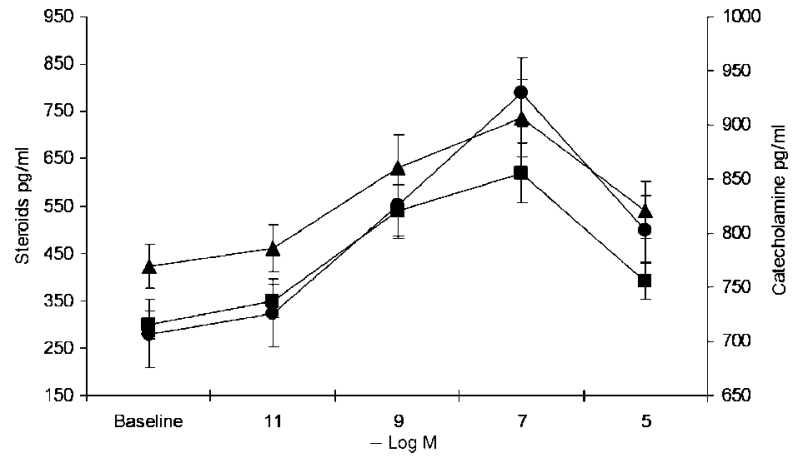

Figure 6 Adrenal cell co-culture dose-response to PACAP administration. Effect of increasing concentration of PACAP on catecholamine $(\bullet)$, aldosterone ( $\mathbf{\Lambda})$ and corticosterone ( $\mathbf{\square})$ secretion respectively. The lowest concentration that caused a significant increase of catecholamine, aldosterone and corticosterone release was $10^{-11} \mathrm{M}$. Values are expressed in $\mathrm{pg} / \mathrm{ml}$ and means \pm S.E.M. of VIP in the adrenal control as occurs in other vertebrates (Nussdorfer \& Malendowicz 1998). Furthermore, recent studies have shown that the in vivo administration of exogenous VIP acts on adrenal glands of $P$. sicula, enhancing adrenaline production (De Falco et al. 2003). Further, the evolutionary conservation of PACAP in P. sicula (Valiante et al. 2007) suggests an important role of these neuropeptides in the physiology of reptiles.

In the present paper, we studied the PACAP localization in P. sicula adrenal glands. First, we showed by immunohistochemistry that chromaffin cells strongly expressed PACAP in contrast with a weak expression level shown by steroidogenic cells. In order to address whether PACAP was produced and/or stored in chromaffin and steroidogenic cells, we investigated the localization of PACAP mRNA by in situ hybridization. We showed that chromaffin cells synthesized PACAP in agreement with that previously reported in the rat adrenal glands (Kantor et al. 2002). It is noteworthy that in P. sicula both adrenaline and noradrenaline cells contain PACAP, while in the rat adrenal glands only the noradrenaline cells were immunoreactive to PACAP (Shiotani et al. 1995). Further, we showed that 

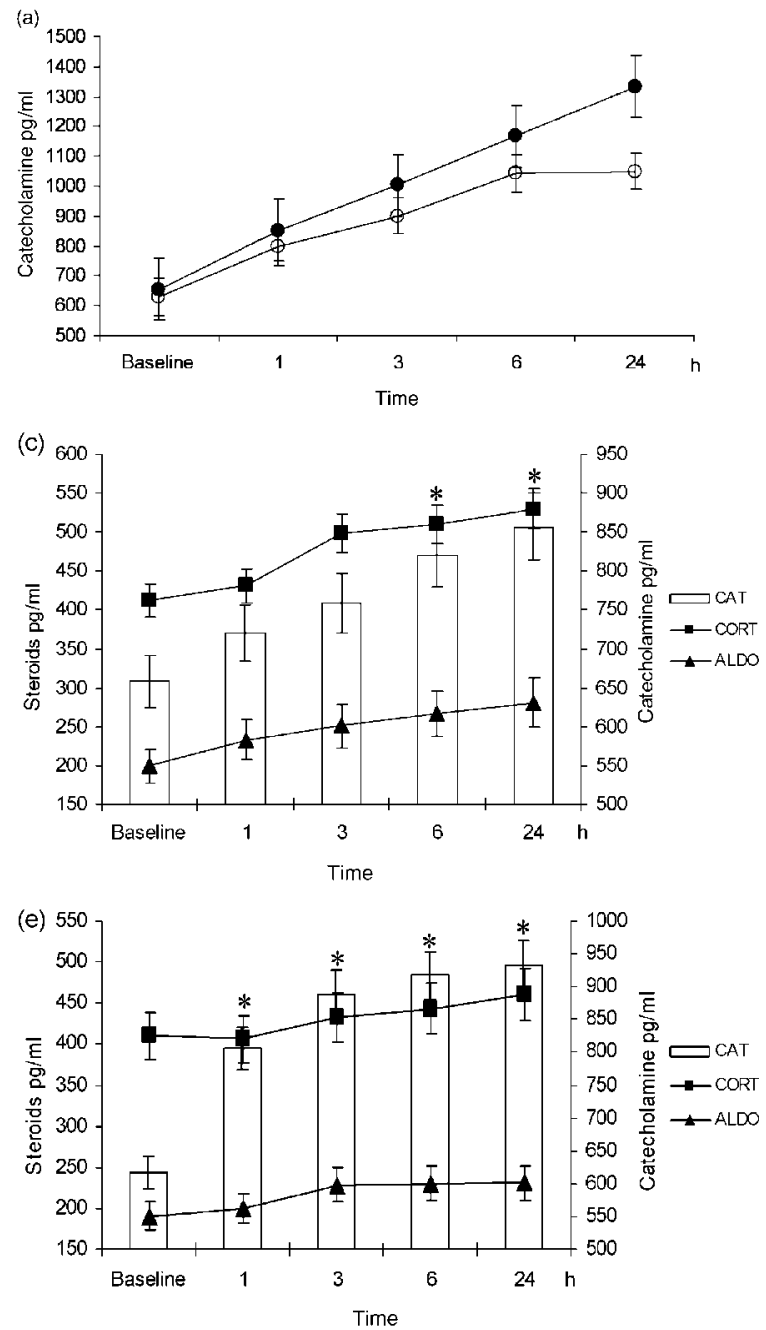
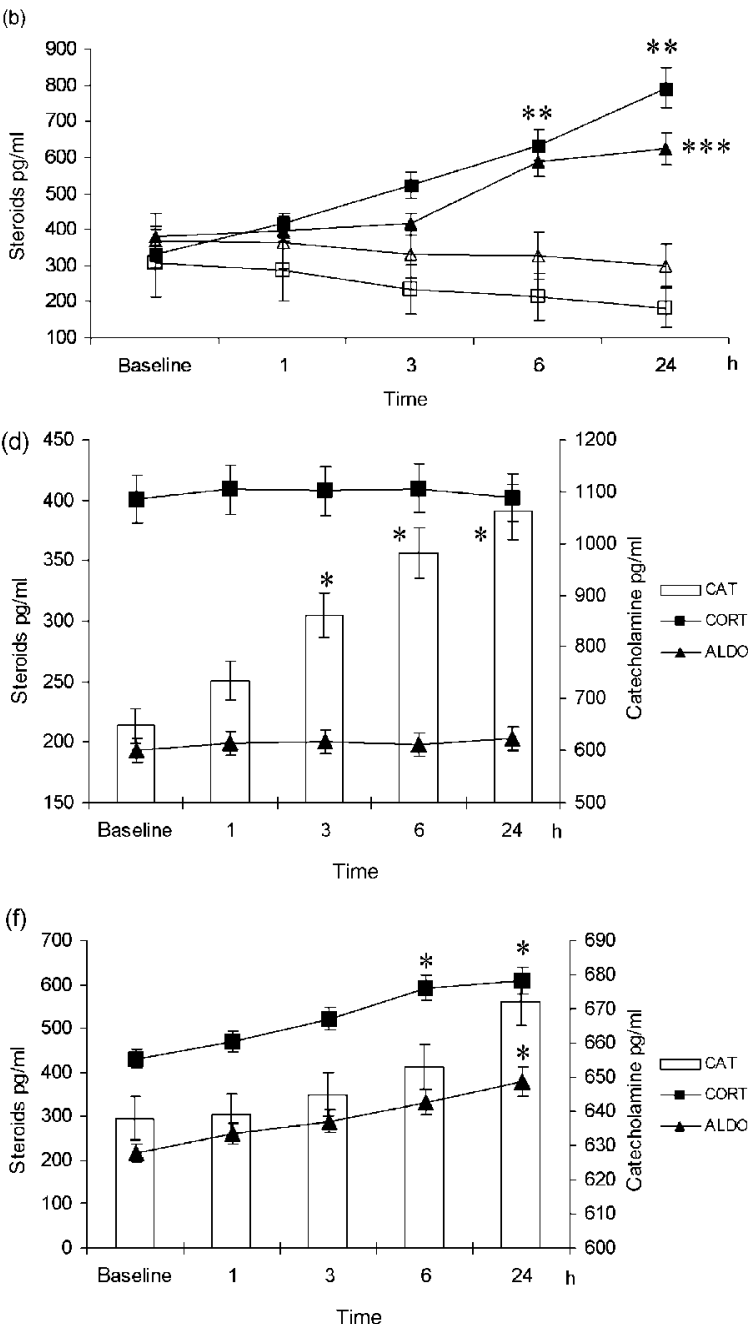

Figure 7 Effect of PACAP $10^{-7} \mathrm{M}$ administration on co-cultured adrenal cells. Data expressed in pg/ml \pm s.E.M. (a) Catecholamine secretion after PACAP $(\bullet)$ and PACAP $+\mathrm{VPAC}_{1}-\mathrm{A} 10^{-6} \mathrm{M}(\mathrm{O}) . P<0 \cdot 05$ versus baseline. (b) Corticosterone (squares) and aldosterone (triangles) secretion after PACAP (black) and PACAP $+\mathrm{VPAC}_{1}-\mathrm{A} 10^{-6} \mathrm{M}$ (empty) administration. ${ }^{* *} P<0 \cdot 01$; *** $P<0 \cdot 001$ versus baseline. $P<0 \cdot 01$ when PACAP is compared with PACAP plus antagonist for aldosterone and corticosterone. (c) PACAP effects through $\mathrm{VPAC}_{1}$ and $\mathrm{VPAC}_{2}$ receptors on catecholamine and steroids secretion. Samples were treated with Propanolol $\left(10^{-6} \mathrm{M}\right)+$ PACAP $6-38\left(10^{-6} \mathrm{M}\right) \cdot{ }^{*} P<0 \cdot 05$. (d) Effects of PACAP administration on catecholamine and steroids through $\mathrm{PAC}_{1}$ receptor exclusively. To block simultaneously $\mathrm{VPAC}_{2}, \beta$-adrenoceptors and $\mathrm{VPAC}_{1}, \mathrm{VPAC}_{2}$ immunoneutralized adrenal cells were treated with PACAP+Propanolol $\left(10^{-6} \mathrm{M}\right)+\mathrm{VPAC}_{1}-\mathrm{A}\left(10^{-6} \mathrm{M}\right) .{ }^{*} P<0 \cdot 05$. (e) PACAP effects on catecholamine and steroids through $\mathrm{VPAC}_{2}$ receptor exclusively. To block simultaneously $\beta$-adrenoceptors, $\mathrm{VPAC}_{1}$ and $\mathrm{PAC}_{1}$, samples were treated with PACAP + Propanolol $\left(10^{-6} \mathrm{M}\right)+\mathrm{VPAC}_{1}-\mathrm{A}\left(10^{-6} \mathrm{M}\right)+\mathrm{PACAP} 6-38\left(10^{-6} \mathrm{M}\right) .{ }^{*} \mathrm{P}<0 \cdot 05$. (f) PACAP effects on catecholamine and steroids through $\mathrm{VPAC}_{1}$ receptor exclusively. To block simultaneously $\mathrm{VPAC}_{2}, \beta$-adrenoceptors and PAC $\mathrm{C}_{1}, \mathrm{VPAC}_{2}$ immunoneutralized adrenal cells were treated with PACAP+Propanolol $\left(10^{-6} \mathrm{M}\right)+$ PACAP 6-38 $\left(10^{-6} \mathrm{M}\right)$ respectively. ${ }^{*} P<0 \cdot 05$.

steroidogenic cells did not produce PACAP mRNA, in accordance with what other authors have reported (Vaudry et al. 2000, Mazzocchi et al. 2002). Thus, it is conceivable that the PACAP immunoreactivity found in steroidogenic tissue may be due to the PACAP secreted by chromaffin cells and bound to receptors exposed on the membrane of steroidogenic cells, since the immunoreactive signal was very close to the plasma membrane of steroidogenic cells, and it disappears when sections of $\mathrm{VPAC}_{1}-\mathrm{A}$-treated adrenals were used.
Secondly, we evaluated the expression of membrane proteins able to bind VIP and/or PACAP using SDS-PAGE in nonreducing condition that allows unaltered receptors to bind ligand (Guse-Behling et al. 1992). We showed, in the lizard adrenals, the presence of two membrane proteins that bind VIP and PACAP ranging between 45 and $55 \mathrm{kDa}$ and a third membrane protein at $60 \mathrm{kDa}$, which binds PACAP exclusively. Since their molecular weights approximately correspond to the known molecular weights of vertebrate $\mathrm{VPAC}_{1}, \mathrm{VPAC}_{2}$ and $\mathrm{PAC}_{1}$ receptors 


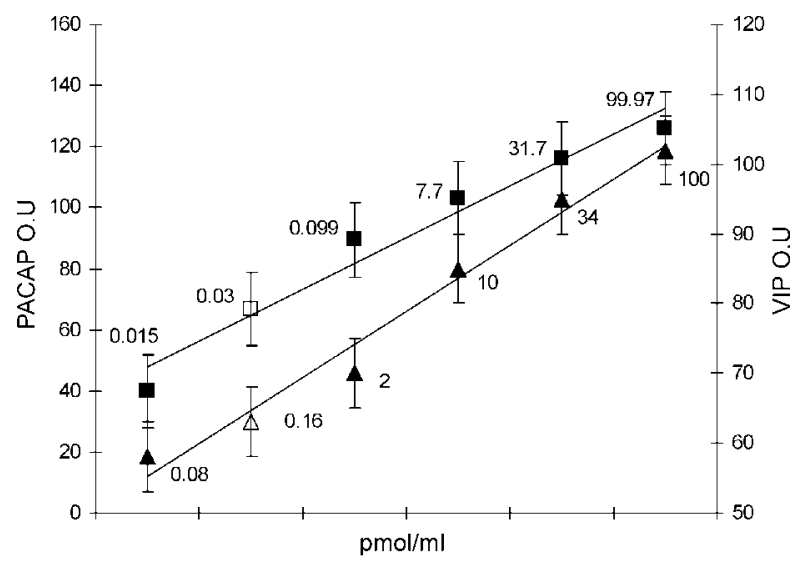

Figure 8 VIP (triangles) and PACAP (squares) dot blot assay. VIP or PACAP pure peptides were used at known concentration to obtain standard curve (black). Medium sample values (empty) are mean of three independent experiments. Kendall coefficient of correlation is $0 \cdot 80$ for PACAP and 1 for VIP. Values are expressed in $\mathrm{pmol} / \mathrm{ml}$. OU, optic units.

respectively, the hypothesis of a complete receptor set expression in the reptile adrenal, as occurs in other vertebrates, is conceivable. Moreover, performing in situ hybridization and immunohistochemistry, we showed a different distribution of the three receptor subtypes: $\mathrm{PAC}_{1}$ receptor is expressed in a few chromaffin cells exclusively and this is in agreement with data available in literature (Vaudry et al. 2000); $\mathrm{VPAC}_{1}$ mRNA and the polypeptide receptor were expressed in the steroidogenic cells, while $\mathrm{VPAC}_{2}$ receptor and its mRNA were found in the chromaffin cells. This is in contrast with the mammalian distribution pattern, since in the rat adrenals there is an opposite association pattern (Usdin et al. 1994) and in humans both receptors are expressed in the zona glomerulosa and in the adrenal medulla (Mazzocchi et al. 2002). This peculiar spatial distribution of chromaffin cells in reptile adrenal, which could be associated with the characteristic pattern of receptor expression, remains to be determined and is an intriguing hypothesis.

Several lines of evidence suggest that chromaffin and steroidogenic cells strongly interact through a crosstalk in autocrine/paracrine manner (Wong et al. 1995, Haidan et al. 1998, Shepherd \& Holzwath 2001). These interactions are mediated by catecholamines and further by several peptides which are secreted by chromaffin cells, acting through specific receptors exposed on both types of tissue (Vaudry et al. 2000). Since it has been previously shown that intra-adrenal communication between adrenocortical and chromaffin cells is essential for the complete hormonal response (Haidan et al. 1998), we performed cell co-culture experiments to preserve the intercellular cross-talking mechanisms.

We demonstrated that the administration of VIP and PACAP affected the secretion of both steroidogenic and chromaffin tissues, enhancing the production of corticosterone, aldosterone and catecholamines respectively. We showed that this was a dose- and time-dependent effect. Our data are consistent with our previous in vivo studies on the adrenal glands of P. sicula (De Falco et al. 2003) and in good agreement with that reported in the literature (Mazzocchi et al. 2002).

Co-culturing chromaffin and adrenocortical cells in the presence of VIP and its receptor antagonist $\mathrm{VPAC}_{1}-\mathrm{A}$, we showed that aldosterone secretion was under the influence of the $\mathrm{VIP} / \mathrm{VPAC}_{1}$ pathway, given that its secretion was decreased by $\mathrm{VPAC}_{1}-\mathrm{A}$. This is consistent with the localization of $\mathrm{VPAC}_{1}$ receptor and its mRNA in steroidogenic cells.

We also observed that corticosterone was only partially affected by $\mathrm{VPAC}_{1}-\mathrm{A}$, implying that an additional signalling pathway should be involved: corticosterone release could be under the paracrine control of catecholamines via $\beta$-adrenoceptors expressed on steroidogenic cells, since it is well known that catecholamines stimulate corticosteroid secretion (Nussdorfer \& Malendowicz 1998): to address this hypothesis, we blocked $\mathrm{VPAC}_{1}$ and $\beta$-adrenoceptors, showing that corticosterone release did not arise; hence, the corticosterone increase in $\mathrm{VPAC}_{1}-\mathrm{A}$-treated adrenal cells should be due to the VIP-evoked release (via $\mathrm{VPAC}_{2}$, which is still active in $\mathrm{VPAC}_{1}-\mathrm{A}$-treated cells) of catecholamines by chromaffin cells in co-cultures, which bind $\beta$-adrenoceptors on the steroidogenic cells.

Catecholamines were not inhibited by $\mathrm{VPAC}_{1}-\mathrm{A}$ but their secretion was completely abolished when $\mathrm{VPAC}_{2}$ immunoneutralized adrenal cells were used, showing that catecholamine release is $\mathrm{VPAC}_{2}$ modulated. This is consistent with the presence of mRNA encoding the $\mathrm{VPAC}_{2}$ receptor in the chromaffin cells solely as shown in our in situ hybridization and immunohistochemistry experiments.

Moreover, we demonstrated that PACAP was able to influence both chromaffin and steroidogenic cells even at very low concentrations $\left(10^{-9} \mathrm{M}\right)$ suggesting the presence of an effective regulation system in the adrenal gland based on this peptide, as already demonstrated in other species (Yon et al. 1994, Mazzocchi et al. 2002). The dose-dependent stimulating activity of PACAP, within a wide range of concentrations $\left(10^{-9} \mathrm{M}-10^{-7} \mathrm{M}\right)$, was highest at $10^{-7} \mathrm{M}$. This is consistent with pharmacokinetics of mammals since it has been demonstrated that PACAP exerts its biological functions between $10^{-8} \mathrm{M}$ and $10^{-7} \mathrm{M}$ (Nussdorfer \& Malendowicz 1998, Mazzocchi et al. 2002).

The stimulation with PACAP produced a secretion pattern with a characteristic time course: a slow increase after just $1 \mathrm{~h}$ and a maximal effect between 6 and $24 \mathrm{~h}$. This time course suggested that PACAP had a long-lasting impact on adrenal cells since after $24 \mathrm{~h}$ its stimulatory activity was enduring for adrenal hormones. This long-term action on both chromaffin and steroidogenic cells could be due to the absence in co-cultured cells of a central negative feedback and/or to the presence of paracrine interactions amongst chromaffin and steroidogenic cells, as previously demonstrated in vitro (Guse-Behling et al. 1992, Haidan et al. 1998, Shepherd \& Holzwarth 2001).

Through the administration of PACAP in co-cultures where only $\mathrm{VPAC}_{2}$ or $\mathrm{PAC}_{1}$ were active, we demonstrated that the $\mathrm{VPAC}_{2}$ and $\mathrm{PAC}_{1}$ receptors are both involved in the PACAPinduced catecholamine secretion and that the PACAP binding to $\mathrm{VPAC}_{2}$ increases catecholamine levels immediately in contrast 
to $\mathrm{PAC}_{1}$, which has a slower effect in time but reaches higher levels. This conclusion is reinforced by the data showing that the $\mathrm{VPAC}_{2}$ receptor and its mRNA were localized in chromaffin cells, while only a small number of chromaffin cells express $\mathrm{PAC}_{1}$. In addition, we showed that PACAP affected steroidogenic cells through interaction with the $\mathrm{VPAC}_{1}$ receptor, since $\mathrm{VPAC}_{1}-\mathrm{A}$ almost completely abolished corticosterone and aldosterone secretion elicited by PACAP and that in $\mathrm{VPAC}_{2}$ immunoneutralized adrenal cells, PACAP is able to increase steroid secretion exclusively. These data further strengthen the significance of $\mathrm{VPAC}_{1}$ presence in steroidogenic cells. Furthermore, unlike VIP, PACAP seems to act on steroid secretion via $\mathrm{VPAC}_{1}$ directly, without the intervention of $\beta$-adrenoceptors, since no PACAP-induced corticosterone release was evident when only $\mathrm{VPAC}_{1}-\mathrm{A}$ was used; if this is a consequence of peptides, different affinity towards the same receptor remains unknown.

Therefore, in the present paper, we showed that chromaffin cells of $P$. sicula synthesize and release not only VIP, as previously demonstrated (Laforgia et al. 1999), but also PACAP. Specifically, we demonstrated that a basal secretion of both VIP and PACAP occurs in vitro and VIP secretion was fivefold higher than PACAP: it is noteworthy that an up-regulation of VIP expression by PACAP has been reported (Vaudry et al. 2000). Drawing from this background, we can affirm that VIP and PACAP are able to influence both chromaffin and steroidogenic cell hormone secretion, by interacting with different receptors. A direct effect of VIP and PACAP on chromaffin cells occurs through $\mathrm{VPAC}_{2}$ and $\mathrm{PAC}_{1}$ receptors, whereas steroidogenic cells can be stimulated through the $\mathrm{VPAC}_{1}$ receptor; whether this stimulation occurs via intracellular different signalling transduction pathways remains to be determined, but what is remarkable is the tissue-specific distribution of these receptors. The presence of PACAP in chromaffin cells allows us to hypothesize that PACAP released from chromaffin cells, either via splanchnic nerve or autocrine stimulation, may influence adrenal cells in a paracrine manner; this statement may be strengthened given that in $P$. sicula steroidogenic and chromaffin tissues are intimately intermingled and thus anatomically situated for such effective 'neural-autocrineparacrine' regulation (Laforgia et al. 1991). The present investigation can be considered a fascinating base in order to clarify the VIP and PACAP roles in reptile endocrinology, since it establishes that, through the existence of multiple receptor pathways, a fine modulation of the lizard adrenal physiology occurs, suggesting that non-cholinergic control is important in the regulation of the lizard adrenocortical and adrenochromaffin cell functions.

\section{Acknowledgements}

We gratefully acknowledge Profs $\mathrm{P}$ Robberecht and M S O'Dorisio for the kind gift of plasmids. In memory of $\mathrm{Mr}$ Giuseppe Falcone who always taught us to look beyond the difficulties. The authors declare that there is no conflict of interest that would prejudice the impartiality of this scientific work.

\section{References}

Andreis PG, Malendowicz L, Belloni AS \& Nussdorfer GG 1995 Effects of pituitary adenylate cyclase-activating polypeptide (PACAP) on the rat adrenal secretory activity: preliminary in vitro studies. Life Sciences 56 135-142.

Bjornsson S 1998 Quantitation of proteoglycans as glycosaminoglycans in biological fluids using an alcian blue dot blot analysis. Analytical Biochemistry $256229-237$.

Bodart V, Babinski K, Ong H \& De Lean A 1997 Comparative effect of pituitary adenylate cyclase-activating polypeptide on aldosterone secretion in normal bovine and human tumorous adrenal cells. Endocrinology 138 $566-573$.

Cao YJ, Gimpl G \& Fahrenholz F 1995 The amino-terminal fragment of the adenylate cyclase activating polypeptide (PACAP) receptor functions as a high affinity PACAP binding domain. Biochemical and Biophysical Research Communications 212 673-680.

Choi JH, Park SY \& Hwang O 1999 Differential involvement of PKA and $\mathrm{PKC}$ in regulation of catecholamine enzyme genes by PACAP. Peptides $\mathbf{2 0}$ 817-822.

Conconi MT, Spinazzi R \& Nussdorfer G 2006 Endogenous ligands of PACAP/VIP receptors in the autocrine-paracrine regulation of the adrenal gland. International Review of Cytology 249 1-51.

Corbitt J, Hagerty T, Fernandez E, Morgan WW \& Strong R 2002 Transcriptional and post-transcriptional regulation of tyrosine hydroxylase messenger RNA in PC12 cells during persistent stimulation by VIP and PACAP 38: differential regulation by protein kinase $\mathrm{A}$ and protein kinase C-dependent pathways. Neuropeptides 36 34-45.

De Falco M, Sciarrillo R, Capaldo A, Laforgia V, Varano L \& De Luca A 2003 Shift from noradrenaline to adrenaline production in the adrenal gland of the lizard, Podarcis sicula, after stimulation with vasoactive intestinal peptide (VIP). General and Comparative Endocrinology 131 325-337.

De Falco M, Sciarrillo R, Virgilio F, Fedele V, Valiante S, Laforgia V \& Varano L 2004 Annual variations of adrenal gland hormones in the lizard Podarcis sicula. Journal of Comparative Physiology A 190 675-681.

Guse-Behling H, Ehrhart-Bornstein M, Bornstein SR, Waterman MR, Scherbaum WA \& Adler G 1992 Regulation of adrenal steroidogenesis by adrenaline: expression of cytochrome p450 genes. Journal of Endocrinology 135 229-237.

Haidan A, Bornstein SR, Glasow A, Uhlmann K, Lubke C \& EhrhartBornstein M 1998 Basal steroidogenic activity of adrenocortical cells is increased 10-fold by co-cultures with chromaffin cells. Endocrinology 139 772-780.

Hall RA 2004 Studying protein-protein interactions via blot overlay or Far Western blot. Methods in Molecular Biology 261 167-174.

Kantor O, Heinzlmann A, Suzuki N, Vincze E, Kocsis K \& Koves K 2002 Distribution of PACAP and its mRNA in several nonneuronal tissues of rats demonstrated by sandwich enzyme immunoassay and RT-PCR technique. Regulatory Peptides 109 103-105

Karacay B, O’Dorisio MS, Kasow K, Hollenback C \& Krahe R 2001 Expression and fine mapping of murine vasoactive intestinal peptide receptor 1. Journal of Molecular Neuroscience 17 311-324.

Laburthe M, Covineau A \& Marie JC 2002 VPAC receptors for VIP and PACAP. Receptors and Channels 8 137-153.

Laemmli UK 1970 Cleavage of structural proteins during the assembly of the head of Bacteriophage T4. Nature 227 680-685.

Laforgia V, Varano L, Capaldo A, Putti R \& Cavagnuolo A 1991 Comparative morphology of the adrenal gland in selected species of the genus Podarcis. Amphibia-Reptilia 12 153-160.

Laforgia V, De Falco M, Capaldo A \& Varano L 1999 Immunohistochemical localization of VIP in the adrenal gland of the lizard Podarcis sicula. Brain Research 848 A22. 
Malagoli D, Lusvardi M, Gobba F \& Ottaviani E $200450 \mathrm{~Hz}$ magnetic fields activate mussel immunocyte p38 MAP kinase and induce HSP70 and 90. Comparative Biochemistry and Physiology, Part C 137 75-79.

Manzo C, Zerani M, Gobbetti A, Di Fiore MM \& Angelini F 1994 Is corticosterone involved in the reproductive processes of the male lizard, Podarcis sicula sicula? Hormones and Behavior 28 117-129.

Mazzocchi G, Malendowicz LK, Rebuffat P, Gottardo L \& Nussdorfer GG 2002 Expression and function of vasoactive intestinal peptide, pituitary adenilate cyclase-activating polypeptide, and their receptors in the human adrenal gland. Journal of Clinical Endocrinology and Metabolism $\mathbf{8 7}$ 2575-2580.

Montpetit CJ \& Perry SF 2000 Vasoactive intestinal polypeptide and pituitary adenilate cyclase-activating polypeptide-mediated control of catecholamine release from chromaffin tissue in the rainbow trout, Oncorhynchus mykiss. Journal of Endocrinology 166 705-714.

Nezlin R 2000 A quantitative approach to the determination of antigen in immune complexes. Journal of Immunological Methods 237 1-17.

Nussdorfer GG \& Malendowicz LK 1998 Role of VIP, PACAP and related peptides in the regulation of the hypothalamo-pituitary-adrenal axis. Peptides 19 1443-1467.

Przywara DA, Guo X, Angelilli ML, Wakade TD \& Wakade AR 1996 A non cholinergic transmitter, pituitary adenilate cyclase-activating polypeptide, utilizes a novel mechanism to evoke catecholamine secretion in rat adrenal chromaffin cells. Journal of Biological Chemistry 271 10545-10550.

Reed DK, Koritko AI, Hipkin RW, Wehrenberg WB, Schonbrunn A \& Cuttler L 1999 Pituitary somatostatin receptor (sst)1-5 expression during rat development: age-dependent expression of sst2. Endocrinology $1404793-4744$.

Shepherd SP \& Holzwarth MA 2001 Chromaffin-adrenocortical cell interactions: effects of chromaffin cell activation in adrenal cell cocultures. American Journal of Physiology. Cell Physiology 280 C61-C71.

Shiotani Y, Shigeharu K, Ohshige Y, Yanaihara C \& Yanaihara N 1995 Immunohistochemical localization of pituitary adenylate cyclase-activating polypeptide (PACAP) in the adrenal medulla of the rat. Peptides $\mathbf{1 6}$ 1045-1050.
Svoboda M, Tastenoy M, Van Rampelbergh J, Goossens JF, De Neef P, Waelbroeck M \& Robberecht P 1994 Molecular cloning and functional characterization of a human VIP receptor from SUP-T1 lymphoblasts. Biochemical and Biophysical Research Communications 205 1617-1624.

Tonshoff C, Hemmick L \& Evinger MJ 1997 Pituitary adenylate cyclaseactivating polypeptide (PACAP) regulates expression of catecholamine biosynthetic enzyme genes in bovine adrenal chromaffin cells. Journal of Molecular Neuroscience 9 127-140.

Usdin TB, Bonner TI \& Mezey E 1994 Two receptors of VIP with similar specificity and complementary distributions. Endocrinology 135 2662-2680.

Valiante S, Prisco M, Capaldo A, Zambrano I, De Falco M, Andreuccetti P, Laforgia V \& Varano L 2007 Molecular characterization and gene expression of the pituitary adenylate cyclase-activating polypeptide (PACAP) in the lizard brain. Brain Research 1127 66-75.

Vaudry D, Gonzales BJ, Basille M, Yon L, Fournier A \& Vaudry H 2000 Pituitary adenilate cyclase-activating polypeptide and its receptors: from structure to functions. Pharmacological Reviews 52 269-324.

Yon L, Chartrel N, Feuilloley M, De Marchis S, Fournier A, De Rijk E, Pelletier G, Roubos E \& Vaudry H 1994 Pituitary adenylate cyclaseactivating polypeptide stimulates both adrenocortical cells and chromaffin cells in the frog adrenal gland. Endocrinology 135 2749-2758.

Yon L, Alexandre D, Montero M, Chartrel N, Jeandel L, Vallarino M, Conlon M, Kikuyama S, Fournier A, Gracia-Navarro F et al. 2001 Pituitary adenylate cyclase-activating polypeptide and its receptors in amphibians. Microscopy Research and Technique 54 37-57.

Wong DL, Siddall B \& Wang W 1995 Hormonal control of rat adrenal phenylethanolamine $N$-methyltransferase:enzyme activity, the final critical pathway. Neuropsychopharmacology 13 223-234.

Received in final form 11 October 2007

Accepted 13 November 2007

Made available online as an Accepted Preprint 13 November 2007 